\title{
A Preliminary Study on the Predicament and Opportunity of Private Higher Education Under the Background of Pan-Education
}

\author{
Ying $\mathrm{Li}^{1, *}$ \\ ${ }^{1}$ College of Artificial Intelligence, Hebei Oriental University, Langfang, Hebei, 000651 China \\ *Corresponding author. Email: yinglimei@163.com
}

\begin{abstract}
In order to find a way out for non-government education in the era of pan-education, this paper studies the characteristics of pan-education and puts forward the concept of pan-education. In the era of pan-education, non-government higher education has encountered great difficulties. This paper discusses the ways of non-government higher education. A new teaching mode QPITE is introduced in this paper, which provides reference for non-government institutions of high learning under the background of pan-education.
\end{abstract}

Keywords: pan-education, private higher education, opportunity, QPITE

\section{INTRODUCTION}

The pan-education discussed in this paper has two meanings: the first is the generalization of the definition of education. Early education mainly refers to the education planned and completed in accordance with the goal of cultivating talents in schools, while general education refers to the activities that enable people to acquire knowledge and skills, which are collectively called education. The second is the generalization of the educational enforcer. The main educators have been generalized from school teachers to school teachers, parents and other institutions and individuals who provide various kinds of knowledge.

\section{HIGHER EDUCATION IN THE CONTEXT OF PAN-EDUCATION}

With the constant innovation of technology, a variety of network education tools are constantly emerging, education has been transformed from "school education as the fundamental" to the era of pan-education. In the context of pan-education, education providers are no longer mainly schools and families, but a variety of training companies and some online voluntary instructors. And the students' learning is also changed from school education which is mainly completed by the school to pan-education which integrates social education, school education and family education. The number of years of learning is also changed from the previous limited number of years to lifelong learning.

In his book The End of The University: The Ubiquitous University and The Revolution in Higher Education, Kevin Carey from the United States defined the parts related to the universal education and higher education with the term "ubiquitous University", discussed the conflict between universal education and traditional higher education, and pointed out the direction of higher education reform [1] Xianming Xiang, an education expert in our country, published "Pan-Education Theory" by Shanxi Education Publishing House in January 2002. According to the theory of "pan-education", on the basis of reference to some methods of phenomenology, the phenomenon of education is divided into "the life world education" and "science and education". It points out the basis of the scientific world education significance in the life world [2]. Using sociological and topological methods, the author analyzes the temporal-spatial characteristics of educational phenomena in social life, which is of great enlightening significance.

\section{PRIVATE HIGHER EDUCATION UNDER THE BACKGROUND OF PAN-EDUCATION}

In this paper, the plight of private higher education under the background of pan-education is analyzed in detail, and some successful examples of private higher education are combined to explore the way out for the development of private higher education. Non-governmental institutions of higher learning in China compared with public colleges and universities have a policy on the development of unfavorable factors, students and teachers also corresponding cannot be compared with public colleges and universities, how to develop the non-profit non-governmental institutions of higher learning, this article in view of the generic education under the background of non-governmental institutions of higher learning are studied, put forward the extensive education under the background of non-governmental institutions of higher learning methods and strategies. 
Under the background of extensive education, students' choice of schooling is more diversified [3]. Generally, students can be divided into research type and employment type. Research type, want to find a certain professional direction more in-depth research, and employment type is to find a good job after graduation. Private institutions of higher learning students employment type in the majority. And numerous training institutions and private institutions of higher learning form a strong competitive relationship. In this situation, it is impossible for private institutions of higher learning to blindly imitate the model of public institutions of higher learning according to the previous way of thinking.

Under the background of pan-education, the channels for students to acquire knowledge are more diversified. Students can get a large number of learning resources from the Internet for free. These learning resources are more novel than much knowledge in textbooks. The teachers of private colleges and universities are usually weak, and many teachers are rehired after retiring from public colleges and universities. The ability of these teachers to accept and disseminate new knowledge is relatively weak, unable to attract students to participate in effective learning.

Under the background of extensive education, students pay more attention to the reputation of the school (the reputation of the school can be quickly spread on the Internet and quickly recognized by the society).Under the background of pan-education, the teaching level among colleges and universities is constantly narrowing down. Meanwhile, due to the continuous expansion of university enrollment, the number of college students increases, and the competition objects of college students are all college students. Therefore, students pay more attention to the reputation of the school. The level of the school mainly depends on the efforts of the students, the scientific research level of the teachers and the management level of the school.

\section{THE DILEMMA AND THE WAY OUT OF PRIVATE HIGHER EDUCATION}

On the basis of research at home and abroad, combined with the actual situation of private institutions of higher learning in China, this paper discusses the plight of private institutions of higher learning in China under the environment of pan-education, and puts forward feasible solutions to the plight of private institutions of higher learning by using the method of analysis and comparison.

Table 1. Troubles and Ways out in private higher learning

\begin{tabular}{|c|c|c|}
\hline & Trouble & A way out \\
\hline 1 & $\begin{array}{l}\text { With the expansion of university enrollment and numerous educational } \\
\text { institutions, it is difficult for private higher education to recruit students. }\end{array}$ & $\begin{array}{l}\text { Private institutions of higher learning should make clear their } \\
\text { positioning, find the difference between them and public institutions } \\
\text { of higher learning and training institutions, identify their advantages, } \\
\text { and give play to their strengths. }\end{array}$ \\
\hline 2 & $\begin{array}{l}\text { Under the background of pan-education, the information dissemination } \\
\text { of schools is more rapid and extensive, so it is very difficult for private } \\
\text { colleges and universities to improve their reputation. }\end{array}$ & $\begin{array}{l}\text { Private institutions of higher learning should put the reputation of the } \\
\text { school in the first place, student-centered, focus on the quality of } \\
\text { teaching, improve the teaching effect. }\end{array}$ \\
\hline 3 & $\begin{array}{l}\text { Under the background of pan-education, knowledge is updated very } \\
\text { quickly [4], while some private colleges and universities have weak } \\
\text { teachers or older teachers, so they accept new knowledge slowly. }\end{array}$ & $\begin{array}{l}\text { To improve the salary of teachers and recruit relevant talents from } \\
\text { companies and other research fields, old teachers can play a guiding } \\
\text { role in teaching methods. }\end{array}$ \\
\hline 4 & $\begin{array}{l}\text { Under the background of pan-education, the competition of education is } \\
\text { very fierce, and the traditional private colleges and universities need a } \\
\text { lot of investment. Without financial support from the state, it is difficult } \\
\text { to maintain. }\end{array}$ & $\begin{array}{l}\text { The problem of educational funds is the shortage of private } \\
\text { institutions of higher learning. Although most private institutions of } \\
\text { higher learning will also receive partial support from the state, } \\
\text { compared with the overall needs of schools, it is a drop in the bucket. } \\
\text { The founders of private colleges and universities should set up } \\
\text { fundraising boards and take various ways to raise money. Tuition fees } \\
\text { for students have taken a back seat. It becomes a virtuous circle. }\end{array}$ \\
\hline 5 & $\begin{array}{l}\text { Under the background of extensive education, the enrollment quality of } \\
\text { private colleges and universities is worrying. It has brought many } \\
\text { challenges to school education and management. }\end{array}$ & $\begin{array}{l}\text { It is an indisputable fact in our country that the quality of students is } \\
\text { inferior to that of public colleges and universities. Private institutions } \\
\text { of higher learning need more strict management of students, from } \\
\text { academic performance, physical, psychological and other aspects of } \\
\text { joint training students, students with high quality education. }\end{array}$ \\
\hline 6 & $\begin{array}{l}\text { Under the background of extensive education, it is no longer suitable for } \\
\text { private institutions of higher learning to imitate public institutions of } \\
\text { higher learning for management and teaching. Under the environment of } \\
\text { pan-education, the teaching mode and curriculum of private colleges and } \\
\text { universities need a lot of reform. }\end{array}$ & $\begin{array}{l}\text { Under the background of pan-education, public institutions of higher } \\
\text { learning will also face transformation. Under such circumstances, } \\
\text { private institutions of higher learning are no longer imitating public } \\
\text { institutions of higher learning and can realize their own } \\
\text { transformation more quickly. In the teaching mode, a combination of } \\
\text { various educational means is adopted to attract people's interest in } \\
\text { learning, deepen students' understanding of the problem, and make it } \\
\text { easier for students to accept. In terms of teaching curriculum, the } \\
\text { traditional higher education based on elite mode is abandoned, and a } \\
\text { systematic talent training program based on vocational practice is set } \\
\text { up [5]. }\end{array}$ \\
\hline
\end{tabular}


Opportunities for private institutions of higher learning under the background of pan-education.

Pan-education also brings opportunities to the development of private institutions of higher learning.

- Under the background of pan-education, the relevant resources of the Internet used by private higher education to invite experts and professors in this field at a lower cost. In public institutions of higher learning, such as Peking University, the teaching mode of "world classroom" has been adopted, in which students can participate in the teaching of world-class universities and communicate with teachers in real time. Some schools have adopted the "MOOC" teaching model to achieve classroom inversion. Under the background of pan-education, there are more and more international exchanges and cooperation of this kind, which is also a good international opportunity for domestic private institutions of higher learning to participate in the education of world-class institutions of $\mathrm{s}$ learning, greatly improve their teaching level and broaden the horizon of students.

- Under the background of pan-education, private higher education combines with off-campus training institutions to provide students with professional knowledge and practice.

- Under the background of pan-education, the teaching mode of private colleges and universities has also changed greatly. Private institutions of higher learning are more flexible than public institutions of higher learning in the establishment of teaching mode [6]. Private institutions of higher learning have greater autonomy and greater flexibility in selecting new teaching modes. Some private institutions of higher learning adopt the teaching mode of integration of production, study and research, which can improve students' practical ability and professional level.

\section{TEACHING MODE QPITE}

This teaching mode involves the whole teaching process, adopts new Internet education technology, attracts students' interest, improves students' understanding, enhances students' practical ability, innovation ability and judgment ability, and cultivates modern college students' ability of cooperation and social communication[7].

The mode mainly for non-governmental institutions of higher learning, focused on solving non-governmental institutions of higher learning in the teaching difficulties, is conducive to the implementation of the better way for the cultivation of the students personalized.

Q: Question. Before the formal start of the class, a questionnaire survey online will be conducted.

P: Plan. According to the students' learning basis and personality traits to make a suitable teaching plan.

IT: Interpret and Test. Teachers play a leading role in class. Using MOOCs or national courses, teachers explain difficult content in the classroom. And to grasp the students' learning situation in real time, some online tests are conducted. Adjust the classroom content in real time according to the test results.

E: Experiment. In order to cultivate students' practical ability and communication ability, the unified single experiment was changed to the group experiment with autonomous reservation.

This teaching mode has been practiced in Hebei Oriental University for 2 semesters and has received good response. The model solves the problems of insufficient teachers, low learning foundation and lack of interest of students in private institutions of higher learning.

\section{CONCLUSIONS}

Under the background of pan-education, private colleges and universities have encountered unprecedented development difficulties. Before entering the era of pan-education, there was only one strong competitor in private colleges and universities, that is, public colleges and universities. Entering the era of pan-education, another opponent of private colleges and universities has become very powerful, that is, a variety of training institutions. Admissions to private institutions of higher learning have become very difficult. The author analyzes the great opportunities existing in private colleges and universities under such circumstances, the systematic teaching methods of colleges and universities, the flexible educational mechanism of private higher education, the solid teaching foundation through various teaching modes, such as online teaching, to reduce teaching costs and improve teaching level, but to be able to compete with public colleges and universities and private institutions of higher learning in a favorable position.

Under the background of pan-education, a new teaching mode QPITE is proposed, which is a new opportunity for private colleges and universities in trouble.

\section{REFERENCES}

[1] Kevin Carey. The End of The University: Ubiquitous Universities and the Revolution in Higher education [M]. Beijing: People's Posts and Telecommunications Press, 2017. (In Chinese)

[2] Xian-Ming Xiang. Pan-education Theory [M]. Shanxi: Shanxi Education Press, 2002.

[3] You Xiaoli. The Trend of "Pan-education" and the Prospect of Universities [N]. China Science Daily, 2019-12-18 (1). (In Chinese)

[4] Liu Geping, Nong Liqiao. From the Theory of "Pan-intelligence" to The Theory of "Pan-Learning Advanced Wisdom Learning": On the Intrinsic Relevance and Value Implication of "Pan-Education" 
Thought [J]. Research on Audio-visual Education. 2020(06): 27-32. (In Chinese)

[5] Shao Kun. In education, open education new future [JB/OL]. China comment. The 2017-11-30 http://www.banyuetan.org/chcontent/jy/jydt/20171130/ 241007.shtml. (In Chinese)
[6] $\mathrm{Su}$ Yi. Reflections on the construction of online open Courses for Higher Vocational Education in a ubiquitous Environment [J]. Time Motors. 2020(19): 62-63. (In Chinese)

[7] Ying Li, Xin-ling Dong, Yue Fan. Research on the QPITE teaching model based on core literacy $4 \mathrm{c}$ in private universities. Adopted by EEIM 2020. 